\title{
Hva er en sårdiagnose, og hvorfor trenger vi den?
}

Mange ikke-helende sår er symptomer på en underliggende tilstand eller sykdom. Derfor er det viktig å stille en sårdiagnose og behandle årsaken til såret først.

\section{Forfattere}

Arne Langøen

Dosent

Institutt for helse- og omsorgsvitskap, Høgskolen på Vestlandet

Marcus Gürgen

Allmennlege i spesialisering og overlege

Kvinesdal legesenter og Kirurgisk avdeling, Sørlandet sykehus, Flekkefjord

Hud Kirurgi Sår sårbehandling Ikke-helende sår

Sykepleien 2019 107(74815)(e-74815)

DOI: https://doi.org/10.4220/Sykepleiens.2019.74815

\section{Hovedbudskap}

Under halvparten av alle pasienter med ikke-helende sår har en sårdiagnose. Sårdiagnosen er helt avgjørende for hvordan såret skal behandles og følges opp. Det er et stort problem at så få pasienter har en sårdiagnose. I denne artikkelen argumenterer vi derfor for at alle pasienter med ikke-helende sår skal få en slik diagnose i løpet av behandlingsforløpet.

Ikke-helende sår, langsomt helende sår eller kroniske sår er begreper som dekker de samme sårene, altså sår som trenger lengre tid enn seks uker på å hele (1). I denne artikkelen benytter vi begrepet ikke-helende sår. 
De aller fleste sår oppstår som følge av et traume. Men når de ikke gror, kan det skyldes systemiske sykdommer eller lokale forhold i såret. I mange tilfeller er det en kombinasjon av systemiske forhold og lokale forhold.

Med dette som utgangspunkt kan vi dele ikke-helende sår inn i to:

- Sår der systemisk sykdom er en vesentlig årsak til at såret ikke gror. Disse sårene er gjerne forårsaket av sykdommer som sirkulasjonssvikt (arteriell og/eller venøs), diabetes eller lammelser som fører til trykkskader.

- Sår der forhold i eller rundt såret er årsaken til at såret ikke heler, heretter kalt posttraumatiske sår. I denne gruppen finner vi postoperative komplikasjoner, hudavskrapninger, brannsår som ikke gror, og liknende. Posttraumatiske sår er altså sår der en ytre skade, sammen med lokale forhold i såret, fører til et sår som ikke gror.

\section{Årsaken til såret}

Det finnes også sår som oppstår spontant uten noen form for traume eller bare ved et ubetydelig traume. Disse sårene er forårsaket av systemisk sykdom som fører til dannelse av sår.

Sårtyper her er for eksempel kreftsår som følge av enten primær tumor til huden eller en metastase fra annen tumor, vaskulitter (betennelse i blodårene) eller pyoderma gangrenosum (ulcerativ, inflammatorisk sykdom som opptrer sjelden og spontant uten kjent årsak).

\section{«Å behandle sårets bakenforliggende årsak er i de fleste tilfeller viktigere enn lokalbehandlingen.»}


Prinsipielt er det viktig å skjønne at mange ikkehelende sår er symptomer på en underliggende tilstand eller sykdom som gjør at såret ikke gror. Det er derfor meget viktig å utrede pasienten med tanke på å finne en eventuell bakenforliggende årsak. Å behandle sårets bakenforliggende årsak er i de fleste tilfeller viktigere enn lokalbehandlingen.

\section{Sårpasienter i Norge}

Hvor mange sårpasienter finner vi i Norge? Det er utfordrende å svare på dette spørsmålet. Dels skyldes det at vi knapt har noen norske undersøkelser som har kartlagt antallet. Samtidig spriker resultatene fra land rundt oss såpass mye at det er vanskelig å være eksakt.

I denne artikkelen bruker vi to ulike begreper som beskriver antallet sår i undersøkelser:

- Prevalensen av ikke-helende sår er andelen personer som på et gitt tidspunkt har et sår som ikke gror.

- Insidensen av ikke-helende sår er andelen personer som jevnlig får et sår på grunn av for eksempel venøs svikt, komplikasjoner av diabetes eller lammelser som forårsaker trykksår.

En tysk epidemiologisk undersøkelse fant en insidens av ikke-helende sår på 1,07 prosent. Det vil si at 1 prosent av befolkningen hadde et ikke-helende sår i løpet av en treårsperiode (2). Khalil (3) hevder at 2 prosent av Australias befolkning har ett eller flere ikke-helende sår. Overført til norske forhold skulle det bety at mellom 50000 og 100000 personer har sår som ikke gror i løpet av en tidsperiode.

Forskjellen på disse tallene kan blant annet skyldes at den tyske undersøkelsen bare tok med sår forårsaket av systemisk sykdom. Ulike traumesår utgjør mellom 30 og 50 prosent av pasientene med ikke-helende sår. Hadde disse blitt inkludert i den tyske undersøkelsen, ville tallene vært likere. 


\section{$\equiv$ «Vel 15000 mennesker har til enhver tid ikke- helende sår.»}

Prevalensen av sår er naturlig nok mye lavere. Tall fra England tyder på at rundt 0,3 prosent av befolkningen til enhver tid har et ikke-helende sår $(4,5)$. Overført til norske forhold skulle det bety at vel 15000 mennesker til enhver tid har ikke-helende sår.

\section{Fordeling av sårgrupper}

Det varierer veldig hvordan sårene defineres. Generelt utgjør posttraumatiske sår den største gruppen. Jelnes (5) fant at 21 prosent av pasientene på sårpoliklinikken i Sønderborg i Danmark hadde ulike former for posttraumatiske sår, mens Khalil (3) fant at hele 56,1 prosent av sårene som var behandlet på en distriktsklinikk i Australia, var posttraumatiske.

I en svensk undersøkelse gjort i kommunehelsetjenesten kom de frem til følgende fordeling (7):

- post-traumatiske sår 33,6 prosent

- trykksår 18,1 prosent

- venøse sår 15,8 prosent

- diabetessår 6,5 prosent

\section{三 «Vi ser at sår forårsaket av diabetes øker $i$ antall og utgjør en stadig større del av sårbehandlernes arbeidstid.»}


Hvordan gruppene defineres, og hvor undersøkelsen gjøres, vil i stor grad bestemme fordelingen mellom dem. Det har vært en utvikling over tid på dette området. Vi ser at sår forårsaket av diabetes (nevropatiske, iskemiske og nevroiskemiske sår) øker i antall og utgjør en stadig større del av sårbehandlernes arbeidstid. Årsaken er en økning i diabetes $2 \mathrm{i}$ befolkningen - en økning vi enda ikke har sett toppen av.

\section{Ulike sårdiagnoser}

Det opereres gjerne med to typer sårdiagnoser (1):

Etiologisk sårdiagnose. Denne diagnosen sier noe om årsaken til at et sår oppstår. Den sier også noe om hvilken eller hvilke grunnsykdommer som forårsaker såret. Venøse leggsår er et eksempel på en etiologisk sårdiagnose.

Morfologisk sårdiagnose. Denne diagnosen sier noe om hvilken tilstand såret befinner seg i. Basert på inndelingen til Schultz og medarbeidere (8) har vi følgende seks klasser:

- rene, granulerende sår

- sår med nekrotisk vev

- sår med bakteriell ubalanse

- sår med betydelig væskeoverskudd

- dårlig oksygenerte sår

- sår med dårlig granulasjonsvev

Etiologisk sårdiagnose skal stilles av en lege, og det bør være en selvfølge at pasienter som sendes fra primærhelsetjenesten til kirurgisk, ortopedisk eller dermatologisk poliklinikk, skal komme tilbake med en pålitelig, etiologisk sårdiagnose (9).

Her er noen eksempler som illustrerer behovet for etiologisk og morfologisk sårdiagnose: 


\section{Bildet viser en fot med et lite sår på andre tå}

PASIENT 1. Eldre mann med et lite sår på andre tå, venstre fot. Personalet i hjemmesykepleien forsøker ulike former for lokalbehandling uten effekt. En enkel ankel/arm-indeks-måling viser AAI (systolisk ankelblodtrykk / systolisk armblodtrykk) $=0,21$ på venstre fot. Det foreligger altså kritisk iskemi i venstre fot, og lokal sårbehandling er nytteløst. Det er ikke aktuelt å gjennomføre rekonstruktiv behandling som blokking eller bypass, og det foretas en amputasjon under kneet en tid etter at bildet ble tatt. (Foto: Arne Langøen)

Tabell 1. Ankel/arm-indeks-måling, tolkning og behandling

\begin{tabular}{llll}
\hline AAI* & Tolkning & Kompresjon & Debridering \\
\hline$>0,9$ & Normal arteriell sirkulasjon & Alle typer & Alle metoder \\
$<0,9>0,7$ & Begrenset nedsatt arteriell sirkulasjon & Kortstrekks-bandasjer & Primært skarp debridering \\
$<0,7>0,5$ & Vesentlig nedsatt arteriell sirkulasjon & Kun Coban 2 Lite & Skarp debridering, men bare med spesialist \\
$<0,5$ & Kritisk iskemi & Ingen kompresjon & Ingen debridering \\
\hline & & & \\
*AAl (systolisk ankelblodtrykk / systolisk armblodtrykk) & & \\
\hline
\end{tabular}

\section{Bildet viser et trykksår som ikke heler}

PASIENT 2: Eldre dame på sykehjem som har et trykksår som ikke heler. Det forsøkes en lang rekke ulike lokale behandlingsløsninger uten at såret vil lukke seg. Sondering av såret viser at det er kontakt inn til halebeinet. Da foreligger det sannsynligvis en osteomyelitt. Denne må saneres før det er mulig å lukke såret. (Foto: Arne Langøen)

\section{Bildet viser et sår på leggen hos eldre dame}

PASIENT 3: Sår på leggen hos eldre dame. Såret kan oppfattes som venøst leggsår, men biopsi viser at det er basalcellekarsinom. Dette såret krever en helt annen behandling (radikal fjerning) enn det som gis til venøse leggsår (lokal sårbehandling og kompresjon). (Foto: Marcus Gürgen)

\section{Bildet viser et stort sår på leggen av ukjent årsak}

PASIENT 4: Stort sår på leggen av ukjent årsak. Såret diagnostiseres i forløpet som pyoderma gangrenosum, et immunologisk sår. Dette såret skal ha en helt annen lokalbehandling enn andre typer sår. Blant annet skal det absolutt ikke debrideres i inflammert fase, og det skal ha omfattende medisinsk behandling med for eksempel kortison. (Foto: Arne Langøen)

\section{Bildet viser et diabetisk fotsår med infeksjon mellom første og andre tå}

PASIENT 5: Diabetisk fotsår med infeksjon mellom første og andre tå. Det gjennomføres en operasjon der abscess åpnes, og puss fjernes. Operasjonen ble ikke vellykket, og en undersøkelse av tåtrykket viste et trykk under $30 \mathrm{mmHg}$. Det må gjennomføres PTA (perkutan transluminal angioplastikk, blokking) før det videre 
arbeidet med foten kan gjennomføres. Pasienten mister deler av forfoten etter dette. (Foto: Arne Langøen)

Bildet viser sår på føttene til en eldre dame

PASIENT 6: Eldre dame på sykehjem som har sår på føttene. Det legges kompresjonsbandasje. Undersøkelsen av foten viser en $A A I=0,25$. Det skal IKKE anlegges kompresjonsbandasje ved kritisk iskemi $(=\mathrm{AAl}<0,5)$. (Foto: Arne Langøen)

Eksemplene er ment å illustrere hvor viktig det er å kjenne årsaken til at såret er oppstått, og eventuelt hvorfor det ikke heler. Uten denne kunnskapen risikerer vi at behandlerne gjør alvorlige feil. Slike feil kan føre til at såret ikke gror, blir verre eller fører til amputasjon, sepsis med videre.

\section{Riktig sårdiagnose}

Den etiologiske sårdiagnosen er basisen for all behandling av såret (10). Det anses som nesten nytteløst å behandle sår uten at man adresserer årsaken bak såret. I praksis viser det seg at mindre enn halvparten av sårene har en slik diagnose. Friman (6) fant at bare 40 prosent av pasientene i deres undersøkelse hadde en etiologisk sårdiagnose.

\section{三 «Det anses som nesten nytteløst å behandle sår uten at man adresserer årsaken bak såret.»}

Legene anser seg som ansvarlige for å stille en slik sårdiagnose, men synes arbeidet er tidkrevende og komplisert. Dessuten opplever de at utdannelsen ikke godt nok forbereder dem på denne oppgaven $(11,12)$. Utfordringen blir da å finne måter å stille sårdiagnose på, slik at vi sikrer at de som daglig behandler sårene, har den informasjonen og kompetansen de trenger for å gjøre denne jobben på en akseptabel måte.

\section{Sykepleien har utviklet et digitalt verktøy for sårvurdering basert på TIMES:}




\section{Referanser}

1. Langøen A, Gürgen M. Sårbehandling, generelle prinsipper. I: Langøen A, red. Sårbehandling og hudpleie. 5 utg. Oslo: Gyldendal Akademisk; 2018.

2. Heyer K, Herberger K, Protz K, Glaeske G, Augustin M. Epidemiology of chronic wounds in Germany: Analysis of statutory health insurance data. Wound Repair Regen. 2016;24(2):434-42.

3. Khalil H, Cullen M, Chambers H, Carroll M, Walker J. Reduction in wound healing times, cost of consumables and number of visits treated through the implementation of an electronic wound care system in rural Australia. Int Wound J. 2016;13(5):945-50.

4. Vowden KR, Vowden P. A survey of wound care provision within one English health care district. J Tissue Viability. 2009;18(1):2-6.

5. Vowden K, Vowden P, Posnett J. The resource costs of wound care in Bradford and Airedale primary care trust in the UK. J Wound Care. 2009;18(3):93-4, 6-8, 100 passim.

6. Jelnes R. Telemedicine in the management of patients with chronic wounds. J Wound Care. 2011;20(4):187-90.

7. Friman A, Klang B, Ebbeskog B. Wound care in primary health care: district nurses' needs for cooperation and well-functioning organization. J Interprof Care. 2010;24(1):90-9. 
8. Schultz GS, Sibbald RG, Falanga V, Ayello EA, Dowsett C, Harding K, et al. Wound bed preparation: a systematic approach to wound management. Wound Repair Regen. 2003;11 Suppl 1(s1):S1-28.

9. Langøen A, Vee TS. Fører systematiske tiltak for å fremme sårbunnsoptimalisering, ødemkontroll og behandling av underernæring til bedret heling av sår. Sår. 2011;19(1):5-12.

10. Langøen A, Gürgen M. Forebygging og behandling av sår. Etiologisk inndeling. I: Langøen A, red. Sårbehandling og hudpleie. 5 utg. Oslo: Gyldendal Akademisk; 2018.

11. Friman A, Wiegleb Edstrom D, Edelbring S. Attitudes and perceptions from nursing and medical students towards the other profession in relation to wound care. J Interprof Care. 2017;31(5):620-7.

12. Friman A. Samverkan och lärande kring sårbehandling - erfarenheter från olika professionsperspektiv i primärvård och utbildning. Stockholm: Karolinska institutet; 2017. 